\title{
Regionalization of Tourist Space in Montenegro According to the Accommodation Facilities
}

\author{
Dašić NedicaA \\ Received: November 2010 | Revised: December 2010 | Accepted: December 2010
}

\begin{abstract}
For tourism development in a specific geographical area, in addition to attractive and communicative factors, it is essential that there are adequate receptive factors, that is, capacities that ensure the reception, lounge and other services to tourists. Their corresponding concentration affects the activation of attractive factors in tourism offer and along with the communication factors that enable tourists to travel, they just give the base to a specific area to obtain the status of a tourist town. In other words, the receptive capacities are the material base of tourism which allow the realization, but also limit the tourist traffic in a specific area. Today, despite the rapid growth of accommodation capacities and tourism activities in Montenegro, an open question of their regionalization in spatial distribution still remains, as the cause and consequence of past and present political and economic conditions in this area. An aim of this paper is to present the current volume, structure and spatial distribution of the accommodation capacities in Montenegro and to provide some new data about their planned future development.
\end{abstract}

Key words: region, sub-region, municipality, accommodation capacity, beds

\section{Introduction}

Since the sixties of the 2oth century, tourism is considered as one of the main directions of economic development in Montenegro. Based on the available wealth of recreational and tourism potentials, significant economic effect on the growth of Gross Domestic Product (GDP), activities of foreign economic relations, equitable distribution of productive forces and the homogenization of economic space, as well as other socio-economic effects, it has a significant growth potential. However, the development path of tourism in Montenegro through history, among other things, was characterized by different time dynamics of construction of accommodation capacities and by exceptional regional disproportion in their spatial distribution. These features of development were best manifested in hotel industry, which suffered numerous ups and downs since 1864 , the year which symbolizes the beginning of hotel evolution in this area. Namely, during the 80's and 9o's of the last century, tourism development came to a halt, even falls within the scope of accommodation capacities and tourist traffic in Montenegro. First it was an earth- quake in I979 that ruined most of the accommodation facilities at the seaside, than the Balkan war, followed by years of sanctions of the international community (I99I-2000) that stopped their further development. According to official statistics, Montenegro had a record offer of accommodation capacities in I988, amounting to 57.220 rooms and I48.4II beds, of which in the coastal towns around $97 \%$. The following drastic decline in volume of statistically registered accommodation capacities reached the minimum in 1992 , accounting for only 85.57I beds. In fact, an outdated methodological framework and classification system of accommodation facilities, years of market distortions, inefficiency in work of some local institutions, certain provisions of law on accommodation industry, etc. led to a significant transfer of private accommodation capacities from legal framework (the official) into the illegal flows, resulting in incomplete statistical records. The statistically recorded "lack" of private accommodation facilities (private houses/flats/rooms) caused a significant (artificial) decrease in the share of complementary accommodation facilities at one side (private accommodation

\footnotetext{
A Faculty of Tourism and Hotel Management, University of Montenegro, Stari grad, 85320 Kotor, Montenegro, e-mail: nedica@ac.me
} 


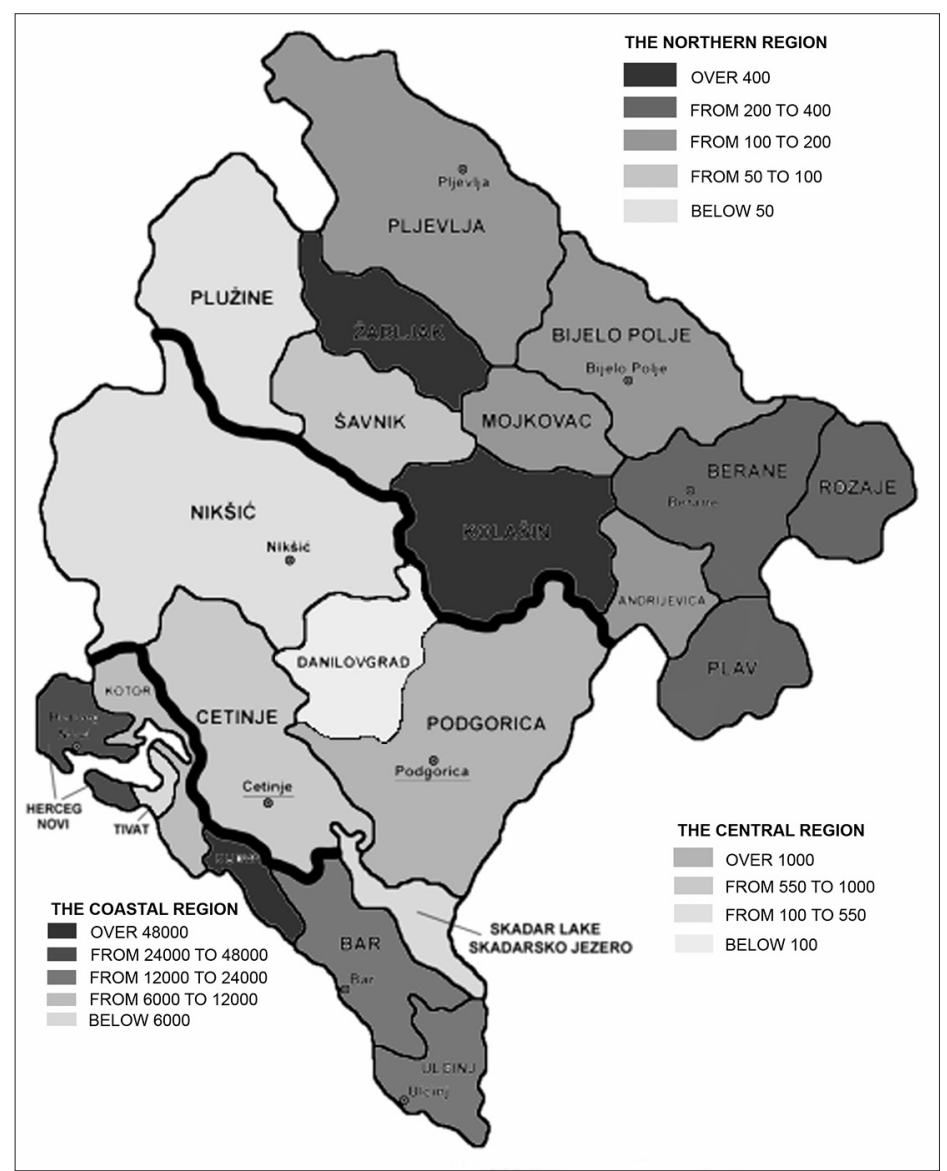

Figure 1. Regionalization of Montenegro according to its tourism regions and accommodation capacities [number of beds] in individual municipalities in 2009

facilities, hiking and hunting lodges, resorts, camps) and an increased participation of the basic ones (hotels, motels, pensions, tourist villas, tourist villages and apartments) at the other side, so that this ratio in 1997 was approximately $60: 40 \%$ in their favor. Since it is inevitable that the share of the complementary accommodation facilities was much higher than the statistics displayed, we could say that the formative force of basic accommodation facilities in the total accommodation offer of Montenegro in this period fell, which impoverished the average quality of total lodging offer and deteriorated the global structure of accommodation facilities, primarily at the expense of hotel industry - the most important one for the market, the economy and new jobs. In addition, due to the lack of capital and small investments in new and modern facilities, in maintenance and renovation of already built ones, the accommodation facilities were characterized as old and insufficiently equipped. This led to significant discrepancies in practice between the official category - quality of supply - price of services, that reflected negatively in many ways. Therefore, the disproportions in the accommodation offer needed to be overcomed by constructions of new basic lodg- ing facilities and reconstructions of existing ones, primarily due to the clear economic benefits that derive from multiple extended period of their use (eg. greater opportunities for wider acceptance of foreign tourist flows, more extensive consumption, higher employment, overcoming the problems that objectively occur during the high season and others). Finally, after thirteen years of regression and stagnation, a slight positive development trend began in 2003, and despite the global economic crisis, the overall accommodation capacity and tourist traffic still grow. Total accommodation offer of Montenegro is about $16 \%$ higher than in the record year (1988), but the share of basic accommodation facilities is still low (Table I). This unfavorable structure of accommodation capacities characterizes some other areas too (eg. France, Germany, Croatia), however, in most European countries the share of basic accommodation facilities is over 50\% (eg. Spain, Greece, Malta) (http:/ epp.eurostat.ec.europa.eu).

Directly and indirectly, in 2009, Montenegro's travel and tourism economy contribution to GDP was an estimated EUR759.I mn or $27.8 \%$ of total GDP, and to employment 31.00o jobs or $20.3 \%$ of total employment. The direct impact was an estimated EUR $385 \mathrm{mn}$ or $\mathrm{I} 4 . \mathrm{I} \%$ of total GDP, representing 16.000 jobs or $10.3 \%$ of total emloyment. According to World Travel and Tourism Council (WTTC, 2009), Montenegro's travel and tourism is expected to continue to rise over the next ten years, achieving real annual growth of $7.4 \%$ in direct industry GDP (up to EURI.059 $\mathrm{mn}$ in 2019), $4.7 \%$ in direct industry employment (up to 25.290 jobs in 2019), $5.2 \%$ in economy GDP (up to EURI, $685.9 \mathrm{mn}$ or $30.6 \%$ in total GDP in 2019 ) and $2.5 \%$ in economy employment (up to 40.000 jobs or $23.5 \%$ of total employment in 20I9). These forecasts put Montenegro in the fifth place in terms of annual growth of contribution to economy GDP (after Russia, Croatia, Slovak Republic and Poland) and in the first place in terms of annual growth of contribution to economy employment (ahead of Croatia, Slovak Republic, Macedonia, Russia). In Central and Eastern Europe, the trav$\mathrm{el}$ and tourism economy is espected to post average annual gains of $5.7 \%$ between 2010 and 2019 , and by $4 \%$ worldwide. In general, tourism development is very important for the Mediterranean destinations such as Montenegro, for it largely influences the development of a whole set of other branches (hotel industry, transportation, telecommunication, catering, trade industry, agriculture...) and therefore affects the development of certain areas and the whole country. The future tourism development in Montenegro is based on the updated Master Plan in 2008 (The innovative strategy for tourism development in Montenegro by 
2020), which emphasizes the sustainable tourism development, based on the preserved natural and cultural heritage, accompanied by an adequate quantitative and qualitative structure of accommodation facilities. In this respect, three natural environments with different tourism potentials can be distinguished in Montenegro (Figure I):

- The Coastal region (The Seaside)

- The Central Region (The Karts field zone) and

- The Northern region (The High mountain region).

A slight share of northern and central municipalities in the total accommodation capacity of Montenegro, directs most of the tourism studies to the coastal area. This marked disproportion in former development between the regions, as a result of many economic and political conditions, needs to be mitigated or even eliminated by precisely planned and controlled future tourism development. In addition, an appropriate volume, structure and quality of accommodation facilities is one of the main preconditions, since most of the previous accommodation facilities and tourism infrastructure were adapted to mass and not sustainable tourism.

\section{The Coastal Region}

The Coastal region of Montenegro or the Montenegrin coast from the spatial aspect includes the marine waters of the coast with islands and the coastland (Radovic, 20Io). Its border with the continental hinterland is made by mountains Orijen, Lovcen, Sutorman and Rumija, spreading from the border with Croatia and Bosnia in the west, to the Albanian border in the east. Along these coastal areas, from ancient and Roman times, the most important and most attractive urban and rural settlements were formed, alternating the various peoples and cultures. From the ancient Ulcinj, Bar, Budva and Kotor to the modern tourist resorts and centers, numerous testimonies of different eras and directions of cultural and artistic creativity have been left, from prehistory and antiquity through the medieval period (Romance, Gothic, Renaissance, Baroque, Rococo) to modern and contemporary artistic expression, evidenced by the rich cultural and historical heritage. Therefore, the highest concentration of immovable cultural monuments is located in this area. From the tourism and hotel industry development aspect, although influenced by numerous political and economic factors, we can say that this region had a special historical significance, particulary two areas that gravitate to this part of Montenegro. The Bay of Kotor as the first one, because of its developed maritime traffic and geostrategic posi- tion in the Adriatic and Cetinje as the second one, because of its political - administrative and diplomatic function as the residence of state. In addition, in these areas the first hospitality facilities, so called hans and bars emerged, and later the hotels that allowed the realisation of foreign tourism travel. Special significance had the hotels: "Grand Hotel" or so called "Lokanda" in Cetinje, "Bay", "Balkan", " Savina", "Europe", "Ercegnovi", "Serbian hotel", "Beograd", next to "Bella Vista inn" in Herceg Novi, pensions "Graz" and "Europe" and "Slavija" in Kotor and pension "On a green beach", later called "The Beach" in Zelenika. Budva, Ulcinj and Bar, were mentioned only in the period after World War Il, though and until then there were individual visits and visits of smaller groups, especially in the region of Bar. An intensive tourism development was contributed by connecting Plavnice with Podgorica with railway in 1927 and establishing links by air and bus between Podgorica and Belgrade in I930, but due to the widespread destruction during World War II, until the end of the fifties and early sixties of the twentieth century, the tourist opportunities of these areas were minimally evaluated.

Today, in the Coastal region of Montenegro about $97 \%$ of the total accommodation capacity is concentrated, so we could say that this region was, and still is representative in terms of the historical development of all types of accommodation $\mathrm{fa}$ cilities in Montenegro. However, this area has certain sub-regions, or clusters or development zones that upset coastal municipalities: Herceg Novi, Kotor, Tivat, Budva, Bar and Ulcinj.

The sub-region of Budva or so called development zone of Budva and Petrovac coastland, scoopes the central part of the Montenegrin coast, from cape of Plantamona and rim of Mrčevo fields to Dubovica on the eastern edge of Buljarica. In this sub-region, single villages of municipality of Budva, such as Becici, Miločer and Sveti Stefan, Petrovac, have been affirmed as metropolises of Montenegrin tourism, and therefore precisely in these areas are now found the largest numbers of accommodation facilities in the Coastal region and the whole of Montenegro in general. In total, but also in the accommodation offer of the Coastal region, the individual shares of coastal municipalities are as follows: the municipality of Budva accounts for about $40 \%$, followed by Herceg Novi with about $21 \%$, Ulcinj $13 \%$ and Bar with a share of about $\mathrm{I} 2 \%$, which is vividly shown in the following chart (Figure 2).

However, when it comes to the structure of accommodation facilities in the territory of this municipality, we can say that it is very bad, because its total offer is dominated by complementary accommodation facilities, with their participation 


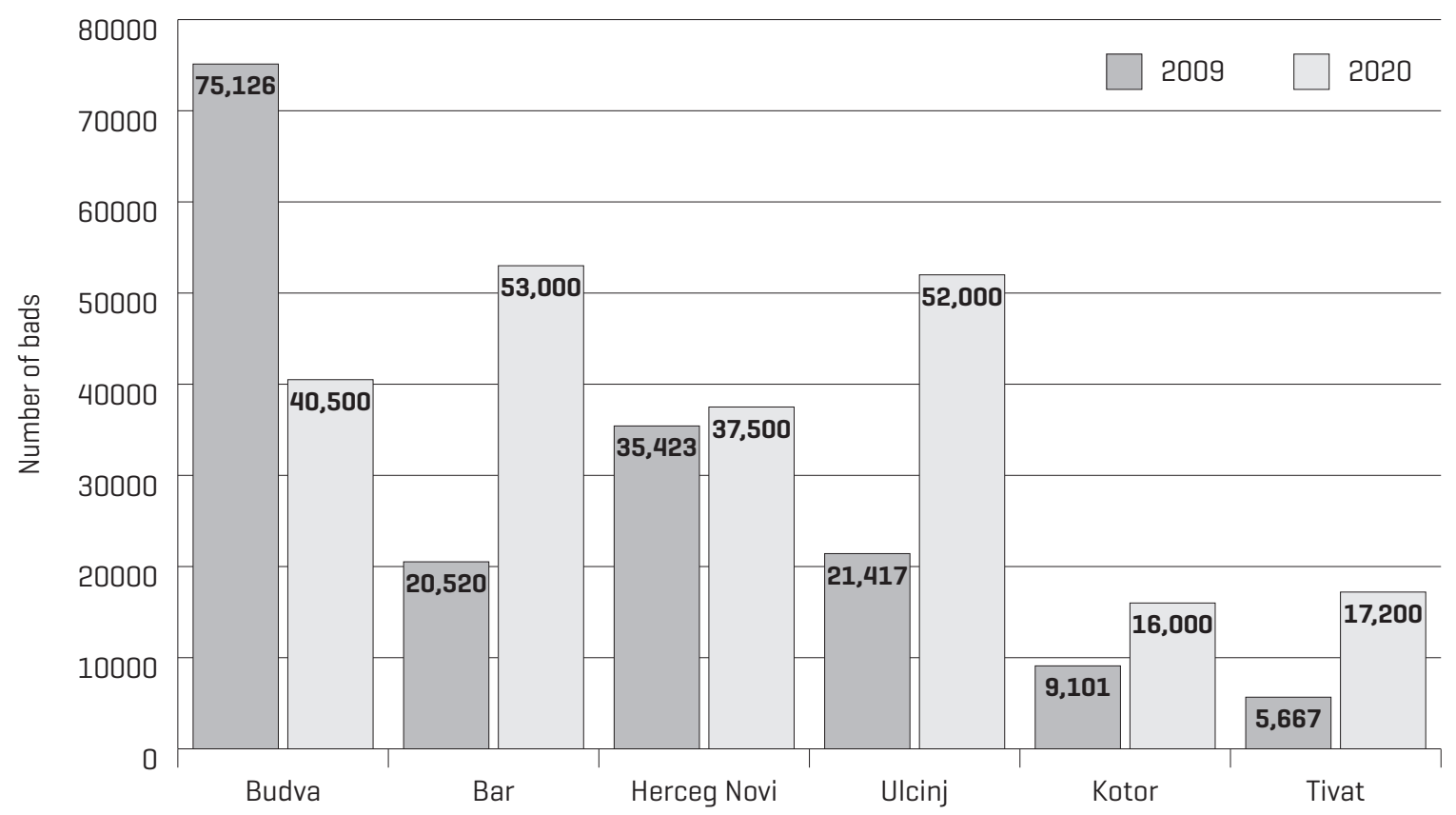

Figure 2. Accommodation capacity [number of beds] of each maritime municipality in 2009 and 2020

of as many as $76 \%$. Within these, private houses and rooms for rent stand out above all with about $62 \%$ of the share, while resorts and camps with the participation of about $9 \%$ and $5 \%$ only complement their overall participation in the accommodation offer of this subregion. Similarly, the share of pensions, motels and tourist villages in the basic types of lodgings, as in all accommodation capacity of Budva is, from the global point of view, almost impercepable, whereas the participation of hotels is only about 19\% (Figure 3). Thus unfavorable structure of accommodation capacity in this part of the Montenegrin coast adversely affected the natural and social environment, but mostly in the form of devastation of many tourist resources. However, according to the Spatial Plan of Montenegro and the updated Master Plan until the year 2020, the percentage of this subregion in the total accommodation capacity of Montenegro in the upcoming period should be reduced in favor of other sub-regions, which will be followed by an increase of the existing quality of hotels on one side and by reduction of number of beds in complementary accommodation facilities on the other side.

The sub-region of Bar is naturally attached to the previous subregion, affecting approximately I $6 \%$ of the coastline in this region, including the beach in Čanj, Sutomore, Bar, Dobre vode and the location Utjeha. In the Spatial Plan of Montenegro this section is treated as a development zone of Bar-Ulcinj Riviera, with two sub-zones: Bar and Ulcinj. Namely, in the area of Bar currently exists about $12 \%$ of total accommodation capacity of Montenegro and the Coastal region, with the participation of the basic accommodation capacities of around 31\%, the hotels and aparthotels with $\mathrm{I} 6 \%$, pensions $2 \%$, tourist villages $\mathrm{I} 3 \%$ and tourist villas $0.3 \%$ (Figure 3). According to the updated Master Plan until the year 2020, or the assessment of development of accommodation facilities in Montenegro, the target accommodation capacity of Bar should be in the amount of 53.000 beds by 2020 , which would increase the participation of the sub-region Bar to $24.5 \%$ in total accommodation offer of the Coastal region. At the same time, it is the largest number of projected accommodation capacities in Montenegro at the end of the given period (Figure 2).

When it comes to the municipality of Ulcinj, which is only $155 \mathrm{~km}$ far from the door of Otrant, or the Ulcinj sub-region whose share in the total length of the Montenegrin coast is II.8\%, it can be said that this is the only area on the Montenegrin coast, which isn't seriously threatened by unplanned and excessive construction of accommodation units. Therefore, it is very attractive for new investments. For now, it possesses 2I.4I7 beds or about $13 \%$ of the accommodation capacity of the Coastal region, of which in private accommodation facilities about $67 \%$, in hotels about $29 \%$ and in tourist villages around $12 \%$ (Figure 3). The aim of the new positioning of Ulcinj in the upcoming period is to be an exceptional, professionally designed international tourism destination all year round, with modern accommodation facilities holding 600 to 800 beds, profiled for different target groups and other attractive facilities (marinas, conference halls, shopping centers, schools, kindergardens, theaters, etc.). Therefore, 
a dynamic construction of accommodation facilities (particularly hotels) is planned, with emphasis on the area of Ada Bojana, Velika Plaža, Peninsula Ratislava, Valdanos, Kruče, and in the hinterland in the area of Šasko Lake.

As for the sub-region of Bay of Kotor, or a spatial zone that includes sub-zones of municipalities of Herceg Novi, Tivat and Kotor, it can be said that it represents a unique geographical, ambiental, cultural and historical entity which, as already pointed out, had a special role in the historical development of tourism and hospitality industry in Montenegro. In the area of Herceg Novi and Kotor, whose share in the total accommodation offer of the coast is 2 I.I9\% and 5.48\%, private accommodation facilities also dominant in the supply with about $74 \%$ in Herceg Novi and about $71 \%$ in Kotor. In Tivat, in contrast to other coastal municipalities, private houses and rooms for rent are not dramatically outweighed with the capacity over the range of other accommodation capacities. Their share of around 50\% is caused by a relatively modest tourist traffic in general, compared to other coastal municipalities, and a smaller number of local residents whose income is gained from tourism in this way. As it can be seen, Kotor and Tivat currently have the least share in the total accommodation offer of the Coastal region, and that would in the realization of the projected accommodation capacity of $\mathrm{I} 6.000$ beds in $\mathrm{Ko}-$ tor and 17.200 in Tivat remain unchanged (Figure 2). Herceg Novi on the other hand, should not significantly increase the existing accommodation offer, which would decline its current participation in the accommodation capacity of the Coastal region by about $4 \%$, due to the implementation of other existing projections. An absolute priority in the future development of this coastal area certainly have a higher category hotel facilities, with special emphasis on small family hotels. On the territory of all three municipalities a new development tourist destination is anticipated, on the move: Mamula - Mirište - Žanjice - Pržno - Bigovo. Specifically, this region has the best and most versatile potential for the development of quality tourism throughout the year, and the main benefits include: the beauty of the ford and mountains associated with the Adriatic, the area for water sports in Tivat - St. Mark, cultural heritage from the Venetian period with Kotor (UNESCO World Cultural Heritage) and Perast, Habsburg's ring of fortresses on the outskirts of the mountains around the Bay (Unique in the world) and almost unaffected spirit of the Mediterranean peninsula Luštice.

Bearing in mind the long-term projection of quantitative content on the Montenegrin coast, according to the Spatial plan of Montenegro un- til the year 2020., the listed sites are determined as the main areas for the development of accommodation capacities.

- The area of the municipality of Herceg Novi, meaning the locations of Kobila, Njivice, Savina, Meljine-Lalovina, Zelenika, Kumbor, Baošići, Arza-Mirište-Žanjice and Lustica.

- For the area of Tivat, priority locations are Pržno- Blue Horizons, Župa and Bonići, as well as revitalization of rural villages provided by appropriate planning documents, Island of flowers and St. Mark; additional capacities are provided on the basis of conversion of a military port and other locations in the tourist zone.

- For the area of the municipality of Kotor, priority locations are Rtac (Risan), Raškov crest (Ljuta), on the land by the open sea in Bigova, above the cliffs of Žukotrlica to Trsten in the Lower Grbalj, in Perast, Upper Stoliv and the captain's palaces in the Gulf.

- For the area of Budva, primarily locations are Bečići, Kamenovo-Miločer, Lučice, Buljarica, Jaz and revitalized rural villages in Paštrovići.

- In the area of the municipality of Bar, priority sites are Čanj, Veliki pijesak, Utjeha and Maljevik.

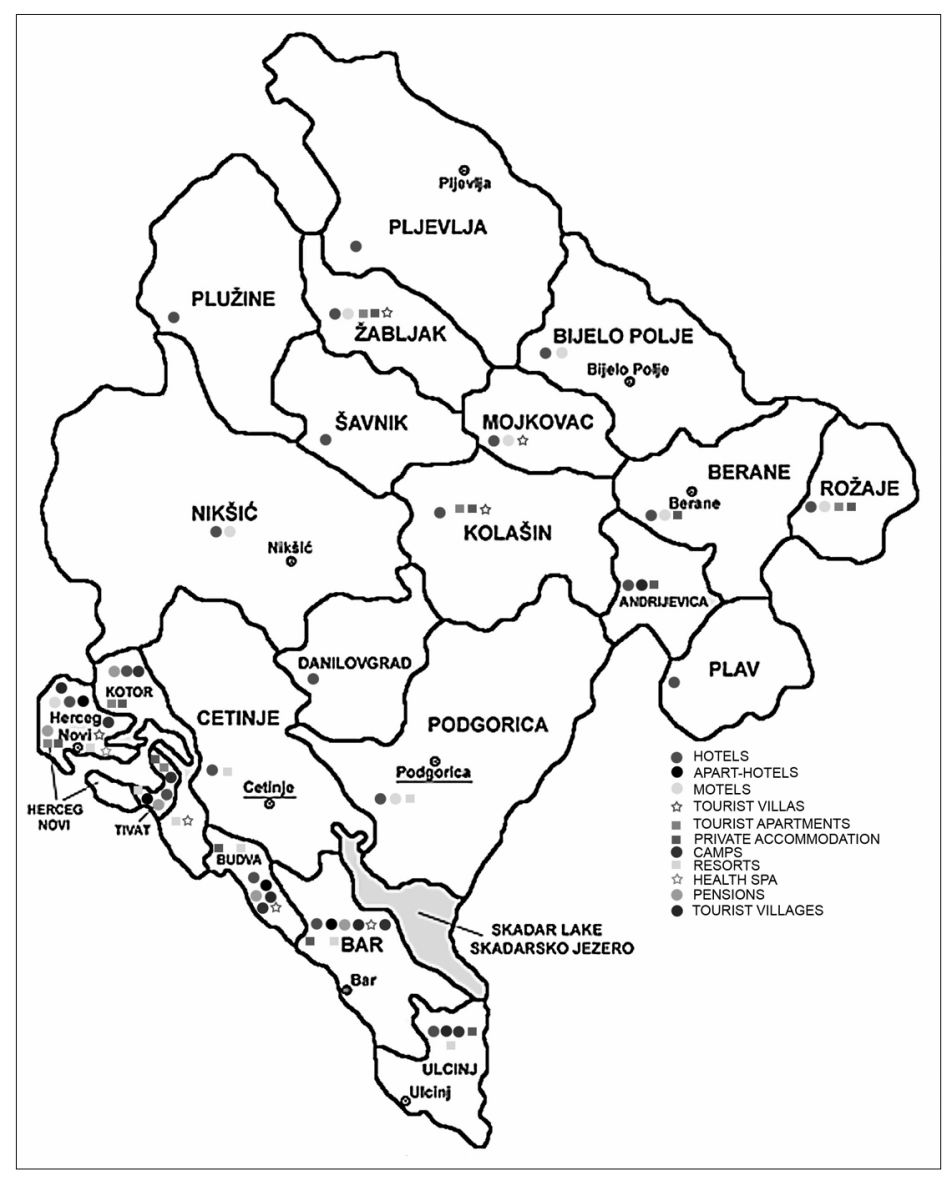

Figure 3. Spatial distribution of different sorts of accommodation facilities in Montenegro in 2009 
- For the area of Ulcinj, priority locations are Valdanos, Velika Plaža with its deep hinterland and Solana and Ada Bojana respecting the principles of sustainable development and natural resources.

Namely, it is assumed that the coastal area will be less crowded with private houses and rooms for rent and that a large part of the current deals will disappear by year 2020 , as they will be used by their owners or will be just rejected by the market because of the insufficient quality. For new constructions, restrictions or limitations on the exclusive high quality are planned, and the main emphasis is on building hotels and similar establishments for vacation use that meet the criteria of higher categories, with a diversified supply through quality specializations focused on target groups.

\section{The Central Region}

In terms of territory, the Central region of Montenegro or so called the Karst plateau with the central valley of Montenegro, is limited with the coastal mountains from the south, with mountains Somina, Njegoš, Pusti lisac and Garač from the central valley, from the East with the Lake Skadar and the Zeta plain up to the gorge Duga and Golija to Krsca in the north. To this region belong the municipalities of Podgorica, Danilovgrad, Nikšic and Cetinje, or all the royal capitals of Montenegro (Žabljak Crnojevića, Obod, Cetinje and Podgorica) that have had a decisive influence on the formation and development of the Montenegrin state through history. In the Central region of Montenegro, which can be devided in subregions of Montenegro holokarst, Skadar Lake, sub-regions of Zeta-Bjelopavlići and Nikšić, there are approximately $37 \%$ of monuments of culture, over $45 \%$ of Montenegro's population but only $2 \%$ of the total accommodation offer (Table I).

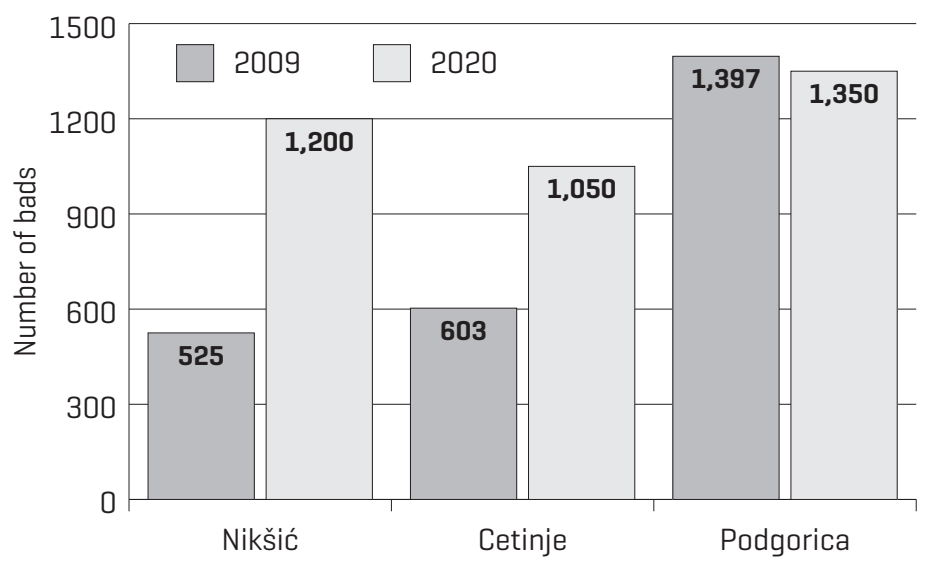

Figure 4. Accommodation capacity [number of beds] of certain municipalities in the Central region in 2009 and 2020
As it can be seen from the chart above, out of 2.6II beds, which was the official accommodation capacity of this part of Montenegro in 2009, more than half are located in the capital (about 53\%) as the administrative center of the state, and then in its residence (about 23\%). The anticipated expansion of the accommodation capacity of Cetinje by the year 2020 up to I.950 beds instead of the current 603 beds, will change the given proportion and make the old capital a main tourist center in the Central region (Figure 4). The participation of Niksic (about 20\%) through only a small number of hotel beds, reflects the lack of strategic orientation of this municipality to develop tourism and hotel industry, or just represents a result of other economic activities' development. In fact, despite the planned formation of Io,0oo hotel beds in this part of Montenegro, which would increase the share of this region in the total hotel offer to about $9 \%$, this area has the potential for developing mostly MICE tourism (acronym MICE: Meetings, Incentives, Conventions/Conferences, Events/Exhibitions), sports tourism, cultural and religious tourism, ie. building capacities that are profiled exclusively to these market segments, transient types of objects such as downtown hotels, motels and type of resorts (children's resorts, workers resorts). Particularly interesting is the possibility of building condo hotels in Podgorica, as a new form of lodging, whose units can be used for either primary residence or as secondary residential units. A condo hotel, also known as a hotel-condo or Condotel, is a building used as both a condominium and a hotel of at least four star level. The accommodation (condominium) units, which are for sale, are owned by several entities and are individually entered into the land register. When aren't used by homeowners, the condo units can be rented and managed as any other hotel rooms. However, the burden of this fairly new concept is that the units must be operated by a management company and in their commercial function for at least Io months during the calendar year ("Official Gazette of Montengro" No. 6I/ıo, Article 4). In any case, the share of hotels and similar establishments on the national level of Montenegro should increase from the current about $20 \%$ to about $37 \%$ in 2020 , and hotels of 4 or 5 star level from the current about $19 \%$ and $\mathrm{I} \%$ to about $38 \%$ and $\mathrm{I} 4 \%$. Hotels of higher categories are primarily intended for the Coastal region (5-star about $14 \%$, and 4-star about $29 \%$ ), and of middle and lower ones for the North and Central region, also called the Hinterland (with 3 stars over $54 \%$, and 2 about $17 \%$ ). This, however, still supports the need for higher quality of accommodation facilities in the Coastal region as a representative part of Montenegro in terms of tourism and hospitality industry. 
Table 1. The involvement of basic and complementary accommodation facilities in total accommodation offer of Montenegro in 2009 and their allocation by main tourism regions

\begin{tabular}{|l|c|c|c|c|c|c|c|}
\hline $\begin{array}{l}\text { Types of } \\
\text { accommodation }\end{array}$ & $\begin{array}{c}\text { Coastal } \\
\text { region }\end{array}$ & Share & $\begin{array}{c}\text { Central } \\
\text { region }\end{array}$ & Share & $\begin{array}{c}\text { Northern } \\
\text { region }\end{array}$ & Share & Total \\
\hline $\begin{array}{l}\text { Basic } \\
\text { accommodation } \\
\text { facilities }\end{array}$ & 38.681 & $88 \%$ & 2.261 & $5 \%$ & 2.918 & $7 \%$ & 43.860 \\
\hline $\begin{array}{l}\text { Complementary } \\
\text { accommodation } \\
\text { facilities }\end{array}$ & 128.713 & $99 \%$ & 350 & $0.269 \%$ & 709 & $0.546 \%$ & 129.772 \\
\hline Total & 167.394 & $96 \%$ & 2.611 & $2 \%$ & 3.627 & $2 \%$ & 173.632 \\
\hline
\end{tabular}

Source of data: Internal documents of Ministry of Tourism

\section{The Northern Region}

The Northern region or the "area of high mountains and surfaces" includes the most part of Montenegro, about $2 / 3$ of its territory, stretching from the mountain of Maglič, Bioče and Volujak over Durmitor, Sinjavina, Bjelasica and Komovi, to the mountain range Prokletije. In this area, there are many natural, economic and tourist resources, among which stand out the river valleys, canyons of European and world value (canyons of rivers: Tara, Morača, Piva, Komarnica, Sušica, Mrtvica, Mala rijeka, Cijevna, Škurda, Čehotina, Ibar, Vruja, Lim), over 35 picturesque mountain lakes and mountain peaks over $\mathbf{2 . 2 0 0}$ meters above sea level, numerous caves (Đalovića cave) and pits (on Vjetrena hills). Officially, the municipalities that belong to this part of Montenegro are Plužine,
Šavnik, Žabljak, Pljevlja, Mojkovac, Kolašin, Bijelo Polje, Berane, Andrijevica, Plav and Rožaje.

Despite the fact that this region has almost $50 \%$ of all potential reception capacities of tourist space in Montenegro and most salient forms of relief, paradoxically, it represents the least developed area, with a total share in accommodation offer of Montenegro from only $2 \%$ (Table I) and $20 \%$ in population.

In this region, the tourist product is still poor and insufficiently attractive, without associated tourist infrastructure to match its rich natural attractions, and therefore, the Ministry of Tourism has defined the mountain tourism as a priority area in the upcoming tourism development. In previous discussions, the issue of tourism development in this part of Montenegro has been treated in the analysis of

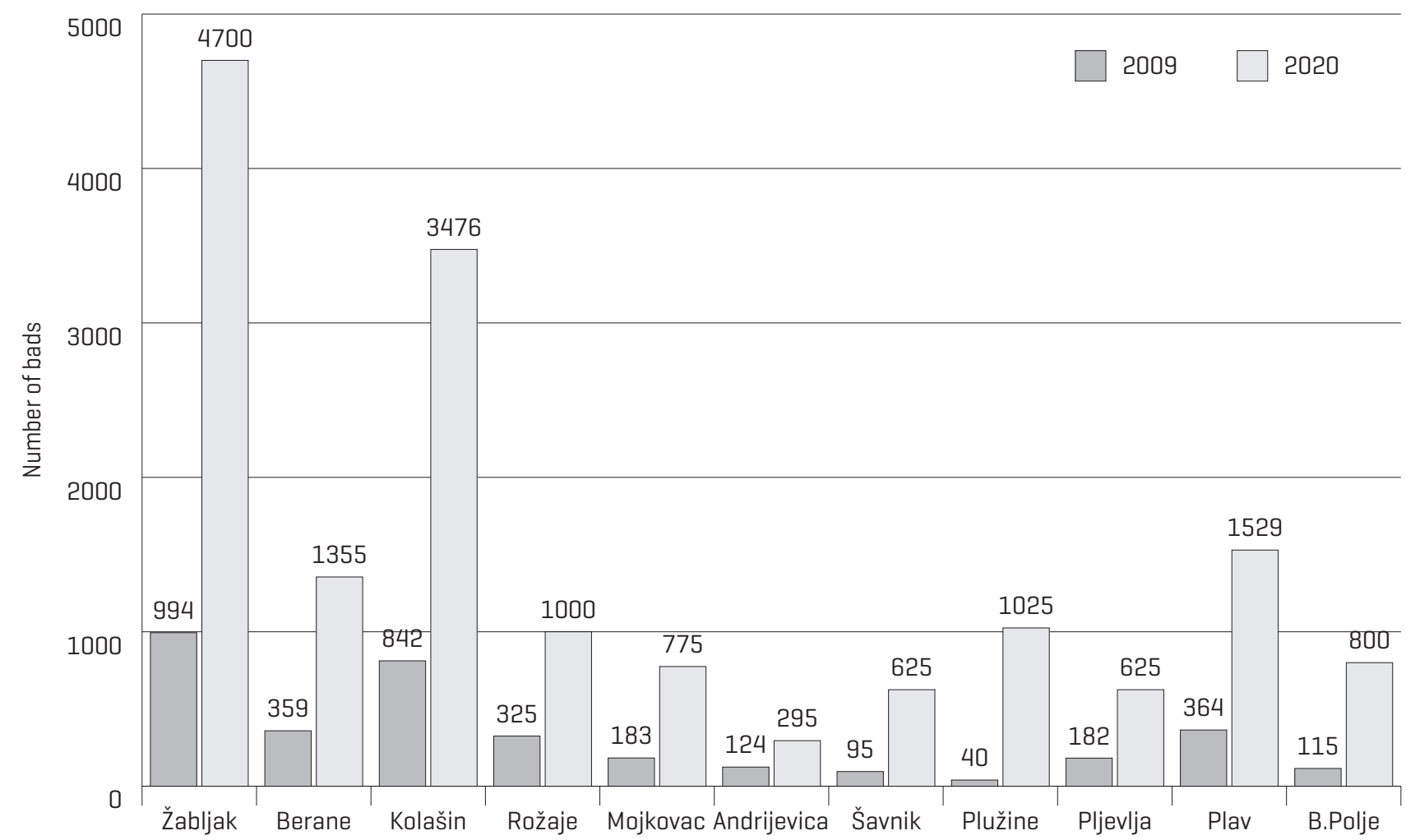

Figure 5. Accommodation capacity [number of beds] of each northern municipality in 2009 and 2020 
numerous development studies, ranging from 8o's of last century, up to the updated Master Plan in year 2008. In general, the Spatial Plan of Montenegro emphasizes the development of different types of tourism according to specific areas of this region, where the Durmitor area includes the municipalities of Žabljak, Plužine and Šavnik, the area Bjelasica \& Komovi the municipalities of Kolašin, Andrijevica, Berane, Bijelo Polje and Mojkovac, Prokletije the municipalities of Plav and Rožaje, and the zone of Cehotina and Ljubovide the area of the municipality of Pljevlja and the northwestern part of the municipality of Bijelo Polje. The main focus of the entire development in this region is on sustainable tourism and alternative forms of tourism and accommodation facilities.

As it can be seen from the figure above (Figure 5), the leader in concentration of accommodation capacites in the mountain area of Montenegro is Žabljak with $27 \%$ of share, followed by Kolašin with $23 \%$ and Plav with 10\%, and then all the other municipalities. Unlike the Coastal region, this part of Montenegro is currently dominated by basic accommodation facilities in overall lodging supply with the share of even $80 \%$ (Figure 3). Still, there is a tendency of growing share of complementary commercial ones, due to insufficient control of unplanned and illegal constructions in this area. According to the projected development of accommodation facilities by 2020, the municipalities of Žabljak, Kolašin and Plav, as the main tourist centers of Durmitor, Bjelasica \& Komovi and Prokletije, will continue to expand their existing accommodation offers, retaining the largest shares in the accommodation offer of this region, followed by the municipalities of Berane, Rožaje and Plužine. Along with the improvement of receptive and communicative conditions in the Northern region, ie, with the development of alternative forms of accommodation facilities such as camps, mountain and eco-lodges that respect the local constructions' style, traditional architecture and materials, as well as the inclusion of tourist information centers, bookmarking for pedestrians and cyclists, the development of local crafts and folk art creation, handling of issues of communal infrastructure in the area of water supply, electricity or solving the problem of parking, traffic, etc.. the necessary conditions for dynamic development of mountain tourism will be made. According to the given forecasts, by 2020 the Northern region should participate in the total number of beds to about $7 \%$ compared to the current $2 \%$.

\section{Conclusion}

From the considerations given above, it is to conclude that the total accommodation capacity of Montenegro is multiple oversized in the Coastal region compared to the possibilities of its natural resources, then disproportionately concentrated in territorial terms, with the primary dominance of complementary accommodation facilities and hotels of middle and lower class. Therefore, the future projections involve the growth of accommodation capacity in almost all municipalities to a projected overall offer of 301.250 beds at the national level, with the primary orientation on the expansion of basic accommodation facilities and reduction of complementary ones, which would be followed by a slight reduction in their disproportional spatial distribution to $93 \%$ : $7 \%$ instead of the current $97 \%$ in the Coastal region and $4 \%$ in the Hinterland. The Coastal region will continue to maintain its distinctive dominance in the future, but with the emphasis placed on qualitative rather than quantitative dimension of development in much greater extent. Other regions will in a synchronized manner, quantitatively and qualitatively, develop the material base of tourism.

\section{References}

Blagojević, S. 2010. Tourism: the economic basis and organizational system. Grafo-press, Novi Sad, 3I8 pp. (in Serbian)

Conrady R., Buck M. 2007. Trends and Issues in Global Tourism 2007. Springer - Verlag Berlin Heidelberg New York, 235 pp.

Horwath HTL. 2009. Horwath Hotel Industry Survey Montenegro 2009. Horwath Consulting Zagreb, Faculty of Tourism, Hospitality and Trade, Bar, Ministry of Tourism of Montenegro, 32 pp. (in Serbian and English)

Ivanović, P. 2009. Montenegro Country Report. Edition 2009. Montenegrin Investment Promotion Agency, Podgorica, 69 pp.

Kosar, Lj. 2008. Hotel Industry I. University of Belgrade, The College of Hotel management, Belgrade, 240 pp. (in Serbian)

Ministry of Tourism and Environment, 2008. The Tourism Development Strategy of Montenegro by 2020 , Io6 pp. (in Serbian)

Ministry of Tourism, 2009. Internal documents (in Serbian).

Ministry of Economic Development, 2008. The spatial plan of Montenegro until 2020, I95 pp. (in Serbian)

"Official Gazette of Montenegro" No. 6r/ıo. Year LXVI. Podgorica, I-24. (in Serbian)

Proceedings of the scientific meeting in Cetinje, 23-24th of May 2002. 2002. Tourism in Montenegro in the second half of the twentieth century. The old capital of Cetinje, Cetinje, Faculty of Economics, Podgorica, Faculty of Tourism and Hotel Management, Kotor, 568 pp (in Serbian) 
Radović, M. 20io. Tourism Geography of Montenegro. Faculty of Tourism, Hotel management and Trade, Bar, Faculty of Tourism and Hotel management, Kotor, 368 pp. (in Serbian with English apstract)

Ratković, R. 2009. Hotel development in Montenegro - genesis, status and perspective. Ivpe, Cetinje, 353 pp. (in Serbian with English preface)
Rutes W.A., Penner R.H., Adams L. 200I. Hotel design-planning and development. Architectural Press, An imprint of Butterworth-Heinemann, London, 422 pp. (in English)

WTTC, 2009. Travel and Tourism Economic Impact-Montenegro 2009, 20 pp. (in English)

http/: www.en.wikipedia.org

http/: /epp.eurostat.ec.europa.eu/ 